\title{
mEiEa
}

\section{Teaching Ethics in the Music Industry Classroom}

\author{
Christopher M. Reali \\ Ramapo College of New Jersey
}

\begin{abstract}
This paper was presented at the 2019 International Summit of the
Music \& Entertainment Industry Educators Association
\end{abstract}

March 21-23, 2019

https://doi.org/10.25101/19.21

\section{Abstract}

Over the past fifteen months, headlines including "Why the Music Industry Hasn't Had Its \#MeToo Moment" and "A Professional's Perspective of Sexism in the Music Industry" have appeared in various sources. These articles, along with the charges against R. Kelly and the revelations about Ryan Adams, serve as reminders that the music industry still has numerous problems to address. But the music industry has long been filled with unscrupulous characters working within the confines of corporate headquarters or those that prey on kids with dreams of becoming the next superstar. Corrupt managers, dishonest agents, shady club owners, and other devious denizens still inhabit all corners of the music industry.

This article considers some ways in which music industry educators can enable students to make smart, principled decisions in regards to the business of music. Teaching ethical business practices in the classroom empowers students to identify how choices in their personal lives and professional careers affects their interactions with others. In the wake of the \#MeToo and \#TimesUp movements and the obstinacy of long-standing industry "rules," the inclusion of learning outcomes that address ethical business practices and leading with high character will better prepare students for careers in the music and entertainment industries.

Keywords: ethics, \#MeToo, \#TimesUp, music management, artist management, code of practice, moral muteness
When Madonna accepted the Billboard "Woman of the Year" honor in 2016, she gave an impassioned speech that addressed sexism, misogyny, and feminism in the music industry. ${ }^{1}$ Others have also been vocal about what Madonna called the "different [industry] rules" for male and female artists. Over the past year, headlines including "Why the Music Industry Hasn't Had Its \#MeToo Moment," "A Professional's Perspective of Sexism in the Music Industry," and "When Will the Music Industry Have Its Weinstein Moment" have appeared in various sources. ${ }^{2}$ These articles, along with the charges against R. Kelly stemming from the documentary about his sexual misconduct allegations, and the revelations about singer Ryan Adams serve as reminders that the music industry still has numerous problems to address. As the old saying goes, the "hits just keep coming." But the music industry has long been filled with unscrupulous characters working within the confines of corporate headquarters or those that prey on kids with dreams of becoming the next superstar. Corrupt managers, dishonest agents, shady club owners, and other devious denizens still inhabit all corners of the music industry.

In order to nurture the future industry leaders, music industry educators must enable our students to make smart, principled decisions. This article considers some ways in which music industry educators can help students develop an ethical and moral compass in regards to the business of music. In other words, helping students to learn how to "do the right thing." Teaching ethical business practices in the classroom empowers students to identify how choices in their personal lives and professional careers affects their interactions with others. In the wake of the \#MeToo and \#TimesUp movements and the obstinacy of long-standing industry "rules," the inclusion of learning outcomes that address ethical business practices and leading with high character will better prepare students for careers in the music and entertainment industries.

\section{Ethics or Morals?}

Hearing or reading the word "ethics" can strike fear into the hearts of some. The term is now fraught with legal implications, and people often conjure images of the PC police 
crashing through the office doors when someone broaches the subject of ethics. The words ethics or morals often describe different concepts. Originally, the word ethics comes from the ancient Greek word ethikos, which means custom or habit. Moralis is a Latin translation of ethikos, so the two words, historically, meant the same thing. But professional ethicists caution against using the terms synonymously. Some suggest using phrases such as, "doing the right thing," or "acting with high character." 3 One way to start a conversation with students about these ideas is to have them debate the differences in terminology, and then stick to whichever term or phrase is agreed upon. After doing this exercise a few times with my students, classes typically prefer the phrase "doing the right thing."

I work at Ramapo College of New Jersey, a public liberal arts college in the northern part of the state. My course load includes three classes per academic year related to the music industry: the Business of Music, a two-hundred level course; and two three-hundred level courses, Advanced Business of Music; and Marketing and Management in the Music Industry. At the beginning of each semester, I take the time to discuss the course learning outcomes with my students. The outcomes that relate to "doing the right thing" include:

1. Be able to identify ways in which one's personal and musical life affects and is affected by interactions with others

2. Develop an ethical and moral compass in regards to the business of music

Throughout the semester, I touch on and directly refer to these outcomes. Regardless of your preferred teaching style, teaching students to "do the right thing" when it comes to the business of music quickly integrates itself into all aspects of the curriculum.

\section{Setting the Stage \& The Lesson}

As the news reports about sexual misconduct allegations in the music industry ramped up during fall 2018, I realized that having some learning outcomes about doing the right thing and reminding students not to be jerks was simply not enough. At the end of the 2018 fall semester, a female student, I'll call her Julie, approached me to ask if she could speak to one of my spring classes about her experiences as a women working in the music industry, and in particular, to discuss her experiences as the president of the Ramapo Music Club, "a vibrant student organization that is dedicated to creating an active music scene on the Ramapo campus." I advise this club, so I have been privy to some of the "issues" Julie has endured. We agreed on a date, and the class took place in mid-March 2019.
I titled the class "\#MeToo and Music," and I partnered with two Ramapo College offices: The Women's Center, and the Office of Violence Prevention. I met with the directors of these offices to discuss my ideas, but I really wanted to hear what they had to say about how to approach such sensitive topics. Since this class was a one-off, we didn't have much time to go into too many details with the students. (I was also informed that the students had already participated in mandated training and education related to these topics.) After we agreed on an overall format, the two directors then met with Julie to help her develop her presentation. The students in the class were assigned five readings. ${ }^{5}$ Before the class, they were also asked to answer the following questions in an online discussion forum:

- How aware were/are you of the \#MeToo and \#TimesUp movements before today's class?

- Have you had any training or education about sexual misconduct or gender discrimination? If so, where and when?

- Have you ever worked at a job where you witnessed ethically questionable behavior or harm?

- How can the music industry promote equality and healthy work environments for all employees?

The class began with a group discussion about these questions. In an attempt to position this particular lesson within the context of the music industry, I showed the students a page from Inclusion in the Recording Studio?, the recent report by the USC Annenberg Inclusion Initiative, that highlighted the very low percentage of women working as artists $(21.7 \%)$, songwriters $(12.3 \%)$, and producers $(2.1 \%)$ within the music industry. ${ }^{6}$ These stats generated a brief discussion which helped set the stage for the next portion of the class.

Simaza Sadek Ishak, the director of the Women's Center, addressed the individual, societal, and institutional behaviors that foster rape culture. The students learned about microaggressions, because that was a big part of Julie's presentation. Microaggressions are defined as, "the everyday verbal, nonverbal, slights, snubs, or insults, whether intentional or unintentional, which communicate hostile, derogatory, or negative messages to target persons based solely upon their marginalized group membership." "7 Marie Attis-Springs, the director of the Office of Violence Prevention, provided background for the students about the \#MeToo and \#TimesUp movements by discussing the roots of these movements in the film industry. The presentations by both Ishak and Attis-Springs established the broad framework for Julie to discuss her experience on the Ramapo campus.

The title of Julie's talk was, "Not Just a Boys Club", a clever play on words that hinted towards the male dominat- 
ed music industry as well as the club that Julie had devoted so much of her time at while at Ramapo. Julie is a drummer who has been an active member of the Ramapo Music Club for each of her four years, holding various executive board positions. The club hosts an open mic every other week, as well as several larger scale music shows per semester. The club has their own budget and gear, including a PA and backline. Julie discussed how male musicians often talked down to her because they assumed she didn't know how to do things because she was a woman. She talked about the frustration of being in the middle of doing something for an event like micing an amp or setting up a drum kit when a male musician would say to her, "Let me help you" or "You're doing it wrong." She remarked that nobody volunteered to help her male counterparts, nor were men criticized when doing the same tasks.

Julie's story was powerful not because it echoed what the students read about for this particular class, which it did. Julie's brief talk impacted my students because it was clear that the headline-grabbing revelations such as the recent Ryan Adams allegations have their roots in seemingly innocuous behaviors that take place in other spaces, often far from the public eye. After Julie's talk, I spoke to the class about "moral muteness," drawing information from the Ethics Unwrapped website hosted by the McCombs School of Business at the University of Texas at Austin. ${ }^{8}$ Moral muteness occurs in two ways, first "when people witness unethical behavior and choose not to say anything," or when individuals "communicate in ways that obscure [his or her] moral beliefs and commitments, or don't voice moral sentiments at all." After a brief discussion, many of the students in my class let it be known that they had witnessed or even (unwillingly) participated in moral muteness.

The New York Times first reported the allegations against Ryan Adams in February 2019. ${ }^{10}$ In a follow-up story about the Adams case, Maura Johnston wrote a piece for Vanity Fair where she harshly criticized those that surrounded the singer for their moral muteness, although Johnston never used that term. ${ }^{11}$ After reviewing the details of the Adams story, I urged my students to lookout for these types of behaviors, particularly if they witness microaggressions like those that happened to their classmate Julie. The root causes for some of these actions run deep, I reminded my class. It was my hope for this particular lesson that if and when faced with similar circumstances, my students would lead with high character.

\section{"Doing the Right Thing"}

In my Advanced Business of Music course I spend several classes teaching ideas connected to entrepreneurship. The topics range from defining entrepreneurship, addressing various business models, to reviewing concepts related to personal finances. Introduction to the Music Industry: An Entrepreneurial Approach, the Catherine Radbill text, serves as one of my sources. ${ }^{12}$ Radbill discusses the fluid definition of the "music professional" within the current industry climate. Regardless of the career path, she reminds the reader:

Transparency in business actions and ethical decision-making are your two guiding lights. The music industry has for too long suffered at the hands of people who are dishonest, self-centered, and focused on profit at all costs. This will only end when music business professionals understand that they are part of the universe, not the center of it, and behave accordingly. Without your integrity, skill, and passion, the creative economy cannot thrive..$^{13}$

This quote, for me, serves two functions: first, it reminds students that character matters; second, the quote functions as a call to action for those who seek careers in the entertainment industries.

I devote about half of my Marketing and Management course to discussing management in varying forms related to the music industry. Since Ramapo is a liberal arts college, I begin the management unit asking students what exactly is management. Some questions I pose include:

- How does an individual acquire the necessary skills to manage?

- What qualities does an effective manager have?

- What, if any, is the difference between a leader and a manager?

For one assignment, I have students interview three people they know who are or were in a management position. The students then write reflection papers about what they learned about management from these interviews and how those ideas relate to the music industry. In class, students write down answers to questions about people who have been in positions of authority over them (parents, teachers, bosses). The students then consider how important charisma, status, honesty, kindness, competence, focus, drive, hard work, and insight are in (a) earning the students' respect and (b) in getting them to perform. The final questions is: What does your answer tell you about the art of managing? My goal here is to get the students thinking broadly and deeply about what it means to manage someone or something.

As we get into topics related to artist management, the students read through different codes of practice from a variety of sources. The first comes from the National Conference of Personal Managers (NCoPM), a "trade association of personal managers who provide management of talent 
engaged in entertainment, media and performing arts."14 The Conference's Code of Ethics includes seven points, three of which are directly related to doing the right thing: "Always deal honestly and fairly with clients; Not derive personal gains at the expense of clients; Treat relationships with clients in a confidential manner." ${ }^{15}$ The Music Manager's Forum (MMF), is a "collaborative network of regional and national membership associations" with branches in multiple countries including the United States. ${ }^{16}$ The MMFUK provides a lengthy, nineteen-point Code of Practice, a few of which are highlighted below. ${ }^{17}$

- Protect and promote the interest of their clients to the highest possible standard;

- Conduct all of their affairs with their clients in a transparent manner;

- Not act in any fashion, which is detrimental to their clients' interests;

- Conduct themselves in a manner which is professional and ethical, and which abides by best business practices and methods and comply with any relevant Statutory Regime and case law that is in place or is created;

- Ensure that no conflict of interest shall interfere with the discharge of their duties towards their clients.

- All conflicts of interest must be disclosed immediately and noted in any artist management agreement.

- The Manager must ensure that the client's money (income and expenditure) is recorded and managed completely separately to the private assets of the manager.

- The MMF shall have the right to terminate a manager's membership if they are convicted of a criminal offence involving fraud, dishonesty, racism, sexual offence or harassment or abuse of minors.

This last point is particularly poignant because it speaks to many of the issues that still plague the music industry. And while none of these organizations have any legal authority, the respective codes demonstrate to the students that there are organizations connected to artist management that passionately care about how their members conduct his or her business. In addition to the Code of Ethics, the MMF also publishes "The Music Manager's Guide to Mental Health."18 These documents provided by the MMF or NCoPM become another resource for students in order to help them learn to do the right thing not only in regards to their clients, but learn to do the right things for themselves, too.

Everything previously addressed serves as a precursor for the case studies and issues I teach associated with artist management. And you can't talk about personal managers without discussing Allen Klein, a legendary figure who served as business manager for both the Rolling Stones and the Beatles. Klein has been described as "a very savvy business man [that some consider to be] a crook. He was probably a little bit (or a lotta bit) of both." ${ }^{19}$ Klein presents an intriguing case study for my students because as Rolling Stones' guitarist Keith Richards once remarked, "Allen Klein made us and screwed us at the same time." For a lesson that I call, "Trust me, I'm your manager," the students read "When the Manager Takes All: You Can't Always Get What You Want," from the Amber Nicole Shavers text, The Little Book of Music Law and "Money To Burn? Allen Klein's Rolling Stones Contracts," by David Philp. The Shavers chapter provides a brief overview of Klein and how he came to act as business manager for the Rolling Stones. As I noted in my review of the Shavers text for the MEIEA Journal, this "chapter provides a cautionary tale by reminding all bands that even the Rolling Stones were susceptible to shady business deals." ${ }^{20}$ Philp used details from the Fred Goodman book Allen Klein: The Man Who Bailed Out the Beatles, Made the Stones, and Transformed Rock $\&$ Roll to provide a close reading of the Stones contracts with Klein. ${ }^{21}$ The Philp article is useful for students because Philp "runs the numbers" by using rather simple math to demonstrate aspects of various contracts that Klein either wrote or renegotiated on behalf of the Stones. Klein certainly made a significant amount of money for the Stones, but he also breached his fiduciary responsibility by lining his own pockets with monies that should have gone into his clients' accounts. After discussing Klein, I find it useful to review the MMF's Code of Practice because many of the points within the code are clearly related to actions or decisions made by managers such as Klein and others.

My students typically write questions related to the assigned readings in advance of a class. I then select a few of the questions to begin the class discussion. Here are a few examples from spring 2018 that allowed students to further probe the ethical conundrum that is Allen Klein: What can we, as students, learn and take away from this mess of a situation? Did this happen to [the Stones] due to their lack of education, or their lack of caring? If some managers are corrupt, why shouldn't artists just manage themselves? (Of course this is a logical reaction, and we spend a good deal of time in other class meetings discussing the pros and cons of self-management.) Would the Stones have achieved the same level of success with a different manager, even though Klein swindled them? This last question gets to the root about "doing the right thing" in regards to your clients. Ultimately, I ask the class, "what would you do?" if you found out your manager acted like Klein?

For this particular class, I also put the students into groups and give them a case study that I wrote that incorporates details gleaned from the articles about Klein. In brief, the 
hypothetical scenario has the students as members of a successful major-label band that finds themselves in need of a manager. The manager vying for the job has many of the same qualities - both good and bad - as Klein. I ask each of the student groups what they, as members of this fictional band, need to consider before signing with this new manager based on the information provided. This exercise prepares students to negotiate as well as consider some "big picture" concepts related to artist management that are not always spelled out in the contract. Overall, this lesson about Klein and the Stones resonates with my students because it makes them aware that even some of the biggest names in music become victims of dishonest characters.

\section{Settlement}

My music industry background includes working as a guitar tech and tour manager for many U.S. and European tours. In my own experiences as a tour manager, I frequently dealt with piles of cash at the end of night. But I never slipped a fifty or even a fiver into my pocket after settlement because I valued my integrity and reputation far more than any possible short-term gains made from skimming off the top of the pile. Transparency in business actions and ethical decision-making were my guiding lights. As an educator, I do my best to impart those same principles to my students.

One of the lines I repeat in class is: "Get some sleep. Eat a salad. Make smart choices." I often joke with students that no matter what they learn from me, I can't make them do the right thing. And while my comment may be pithy, it's also true. The many factors determining a student's individual character are way beyond my control. Yet I spend so much time trying to guide students to make smart, principled decisions because I'm optimistic that if and when a situation arises where they could do wrong to either themselves or their client, they would think long and hard before taking any action. Of course, I tell them that in those soul-searching moments, I hope that they do the right thing.

\section{Endnotes}

1. Madonna's speech is available on YouTube: https:// www.youtube.com/watch? $\mathrm{v}=\mathrm{c} 6 \mathrm{Xgbh} 2 \mathrm{E} 0 \mathrm{NM}$.

2. Michael Arceneaux, "Why the Music Industry Hasn't Had Its \#MeToo Moment," Wired, April 13, 2018, https://www.wired.com/story/music-industry-me-too/; Emma-Lee Moss, "\#MeToo: Emmy the Great Speaks Out About Music Industry Men," GQ, February 19, 2018, https://www.gq-magazine.co.uk/article/emmythe-great-metoo; John Niven, "\#MeToo: Sexism in the Music Industry," GQ, February 15, 2018, https:// www.gq-magazine.co.uk/article/metoo-music-industry; Stacie Huckeba, "A Professional's Perspective On Sexism In The Music Industry," Huffington Post, July 5, 2016, https://www.huffpost.com/entry/a-professionals-perspective-on-sexism-in-the-music-industry b 10762200 .

3. Bruce Weinstein, "Is There A Difference Between Ethics And Morality In Business?," Forbes, February 27, 2018, https://www.forbes.com/sites/bruceweinstein/2018/02/27/is-there-a-difference-between-ethics-and-morality-in-business/\#5c808a8f2088.

4. https://www.ramapo.edu/ca/clubs-honor-societies-ensembles/.

5. Four of the five assigned readings are listed in footnote one. The fifth reading was, Dorothy Carvello, "“Anything For A Hit' Exclusive Book Excerpt: Atlantic Records in the '80s Was Like Plunging Into 'A Circus Mixed with an Orgy,", Billboard, August 3, 2018, https://www.billboard.com/articles/news/8468359/anything-for-a-hit-book-excerpt-atlantic-records-dorothycarvello.

6. Stacy L. Smith, Marc Choueiti, Katherine Pieper, Hannah Clark, Ariana Case, and Sylvia Villanueva, Inclusion in the Recording Studio? Gender and Race/ Ethnicity of Artists, Songwriters \& Producers across 700 Popular Songs from 2012-2018 (USC Annenberg Inclusion Initiative, February 2019), http://assets. uscannenberg.org/docs/aii-inclusion-recording-studio-2019.pdf.

7. Derald Wing Sue, "Microaggressions: More than Just Race," Psychology Today, November 17, 2010, https://www.psychologytoday.com/us/blog/microaggressions-in-everyday-life/201011/microaggressions-more-just-race.

8. "Ethics Unwrapped," McCombs School of Business, The University of Texas at Austin, https://ethicsunwrapped.utexas.edu/.

9. Ethics Unwrapped, "Moral Muteness," McCombs School of Business, The University of Texas at Austin, https://ethicsunwrapped.utexas.edu/glossary/moral-muteness. 
10. Joe Coscarelli and Melena Ryzik, "Ryan Adams Dangled Success. Women Say They Paid a Price," New York Times, February 13, 2019, C1.

11. Maura Johnston, "Ryan Adams, Music's \#MeToo Reckoning, and Who Really Cleans Up After Rock's So-Called Excess," Vanity Fair, March 6, 2019, https://www.vanityfair.com/style/2019/03/musics-metoo-reckoning-ryan-adams.

12. Catherine Radbill, Introduction to the Music Industry: An Entrepreneurial Approach (New York: Routledge, 2017).

13. Radbill, Introduction to the Music Industry, 67.

14. "National Conference of Personal Managers Inc.," http://ncopm.com/.

15. National Conference of Personal Managers, "NCOPM Code of Ethics," http://ncopm.com/about/ncopm-code-ethics/.

16. "IMMF: International Music Managers Forum," http:// immf.com/about-us/s.

17. Music Manager's Forum, "MMF UK Code of Practice \& Framework for Training and Education," Sept. 2017, https://themmf.net/site/wp-content/uploads/2017/11/MMF-UK-Code-of-Practice-and-Trianing-Framework-2017.pdf.

18. Music Manager's Forum, "The Music Manager's Guide to Mental Health," 2017, https:// themmf.net/site/wp-content/uploads/2018/01/Mental-Health-Guide-Digital.pdf.

19. David Philp, "Money To Burn? Allen Klein's Rolling Stones Contracts," Music Biz 101, August 20, 2015, http://musicbiz101wp.com/money-to-burn-allenkleins-rolling-stones-contracts/.

20. Christopher M. Reali, review of The Little Book of Music Law, by Amber Nicole Shavers, Journal of the Music and Entertainment Industry Educators Association 17, no. 1 (2017): 161-167, https://doi. org/10.25101/17.11.

21. Keith Hatschek reviewed Goodman's book for the Journal of the Music and Entertainment Industry Educators Association 15, no. 1 (2015): 225-231, https:// doi.org/10.25101/15.15.

\section{References}

Arceneaux, Michael. "Why the Music Industry Hasn't Had Its \#MeToo Moment." Wired, April 13, 2018. https:// www.wired.com/story/music-industry-me-too/.

Carvello, Dorothy. "“Anything For A Hit' Exclusive Book Excerpt: Atlantic Records in the '80s Was Like Plunging Into 'A Circus Mixed with an Orgy." Billboard, August 3, 2018. https://www.billboard.com/articles/ news/8468359/anything-for-a-hit-book-excerpt-atlantic-records-dorothy-carvello.

Coscarelli, Joe, and Melena Ryzik, "Ryan Adams Dangled Success. Women Say They Paid a Price." New York Times, February 13, 2019, C1. https://www.nytimes. com/2019/02/13/arts/music/ryan-adams-women-sex. $\underline{\mathrm{html}}$.

"Ethics Unwrapped." McCombs School of Business, The University of Texas at Austin. https://ethicsunwrapped. utexas.edu/.

Ethics Unwrapped. "Moral Muteness.” McCombs School of Business, The University of Texas at Austin. https:// ethicsunwrapped.utexas.edu/glossary/moral-muteness.

Hatschek, Keith. Review of Allen Klein: The Man Who Bailed Out The Beatles, Made the Stones and Transformed Rock \& Roll, by Fred Goodman. Journal of the Music and Entertainment Industry Educators Association 15, no. 1 (2015): 225-231. https://doi. org/10.25101/15.15.

Huckeba, Stacie. "A Professional's Perspective On Sexism In The Music Industry." Huffington Post, July 5, 2016. https://www.huffpost.com/entry/a-professionals-perspective-on-sexism-in-the-music-industry b 10762200 .

International Music Managers Forum. "IMMF: International Music Managers Forum.” http://immf.com/ about-us/s.

Johnston, Maura. "Ryan Adams, Music's \#MeToo Reckoning, and Who Really Cleans Up After Rock's So-Called Excess." Vanity Fair, March 6, 2019. https://www.vanityfair.com/style/2019/03/musics-metoo-reckoning-ryan-adams.

Madonna. "Madonna Woman of The Year Full Speech." Billboard Women in Music 2016. https://www.youtube. com/watch?v=c6Xgbh2E0NM.

Moss, Emma-Lee. "\#MeToo: Emmy the Great Speaks Out About Music Industry Men.” GQ, February 19, 2018. https://www.gq-magazine.co.uk/article/emmy-thegreat-metoo.

Music Manager's Forum. "MMF UK Code of Practice \& Framework for Training and Education." $M M F$. Sept. 2017. https://themmf.net/site/wp-content/uploads/2017/11/MMF-UK-Code-of-Practice-and-Trianing-Framework-2017.pdf. 
Music Manager's Forum. “The Music Manager's Guide to Mental Health." MMF. 2017. https:// themmf.net/site/wp-content/uploads/2018/01/Mental-Health-Guide-Digital.pdf.

National Conference of Personal Managers. "NCOPM Code of Ethics.” http://ncopm.com/about/ncopm-code-ethics/.

Niven, John. "\#MeToo: Sexism in the Music Industry." $G Q$, February 15, 2018. https://www.gq-magazine. co.uk/article/metoo-music-industry.

Philp, David. "Money To Burn? Allen Klein's Rolling Stones Contracts." Music Biz 101, August 20, 2015. http://musicbiz101wp.com/money-to-burn-allenkleins-rolling-stones-contracts/.

Radbill, Catherine. Introduction to the Music Industry: An Entrepreneurial Approach. New York: Routledge, 2017.

Reali, Christopher M. Review of The Little Book of Music Law, by Amber Nicole Shavers. Journal of the Music and Entertainment Industry Educators Association 17, no. 1 (2017): 161-167. https://doi.org/10.25101/17.11.

Smith, Stacy L., Marc Choueiti, Katherine Pieper, Hannah Clark, Ariana Case, and Sylvia Villanueva. Inclusion in the Recording Studio? Gender and Race/Ethnicity of Artists, Songwriters \& Producers across 700 Popular Songs from 2012-2018. USC Annenberg Inclusion Initiative, February 2019. http://assets.uscannenberg.org/ docs/aii-inclusion-recording-studio-2019.pdf.

Sue, Derald Wing. "Microaggressions: More than Just Race." Psychology Today, November 17, 2010. https://www.psychologytoday.com/us/blog/microaggressions-in-everyday-life/201011/microaggressions-more-just-race.

Weinstein, Bruce. "Is There A Difference Between Ethics And Morality In Business?" Forbes, February 27, 2018. https://www.forbes.com/sites/bruceweinstein/2018/02/27/is-there-a-difference-between-ethics-and-morality-in-business/\#5c808a8f2088.
Christopher M. Reali is an Assistant Professor of $\mathrm{Mu}-$ sic (Music Industry) at Ramapo College of New Jersey. He holds a Ph.D. in musicology and studies popular music by examining the relationships between local music scenes and the national music industry. He is currently working on a manuscript about the Muscle Shoals, Alabama recording industry. This work situates the Muscle Shoals music scene within the larger narrative of popular music studies by assessing salient musical characteristics and interpreting the long-lasting cultural effects of this Alabama community. Reali has presented at numerous conferences including the American Musicological Society, the Society for American Music, the Society for Ethnomusicology, the U.S. conference of the International Association for the Study of Popular Music, and the MEIEA Summit. His published work appears in Rock Music Studies, MEIEA Journal, Southern Cultures, The New Grove Dictionary of American Music, and The New Encyclopedia of Southern Culture. Dr. Reali has also toured the United States, Canada, and Western Europe as a guitar technician and tour manager for Chris Whitley, and as a guitar, bass, and drum tech for David Gray.

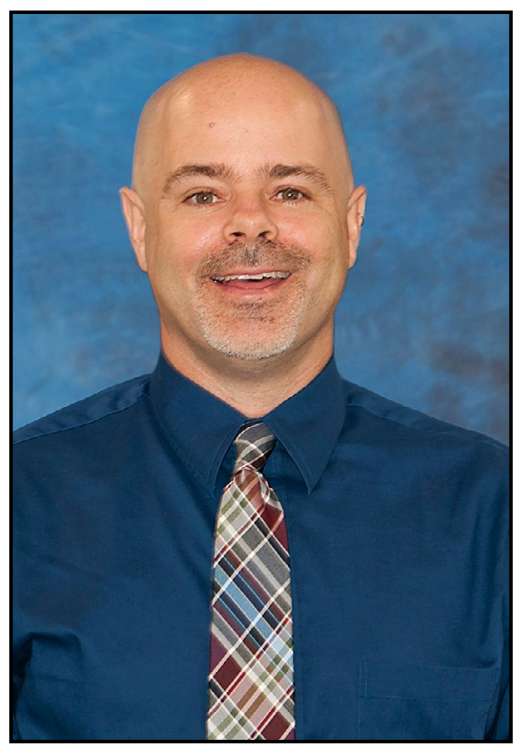




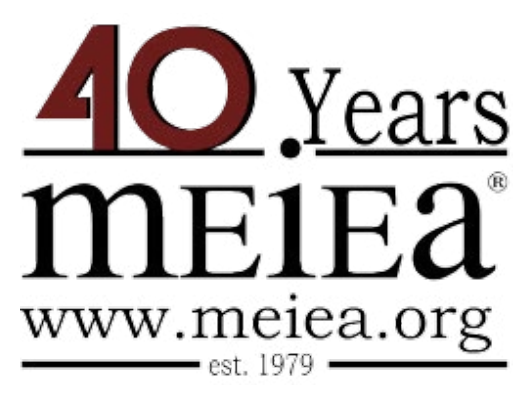

\section{PROCEEDINGS OF THE \\ 2019 INTERNATIONAL SUMMIT \\ OF THE \\ MUSIC \& ENTERTAINMENT \\ INDUSTRY EDUCATORS \\ ASSOCIATION}

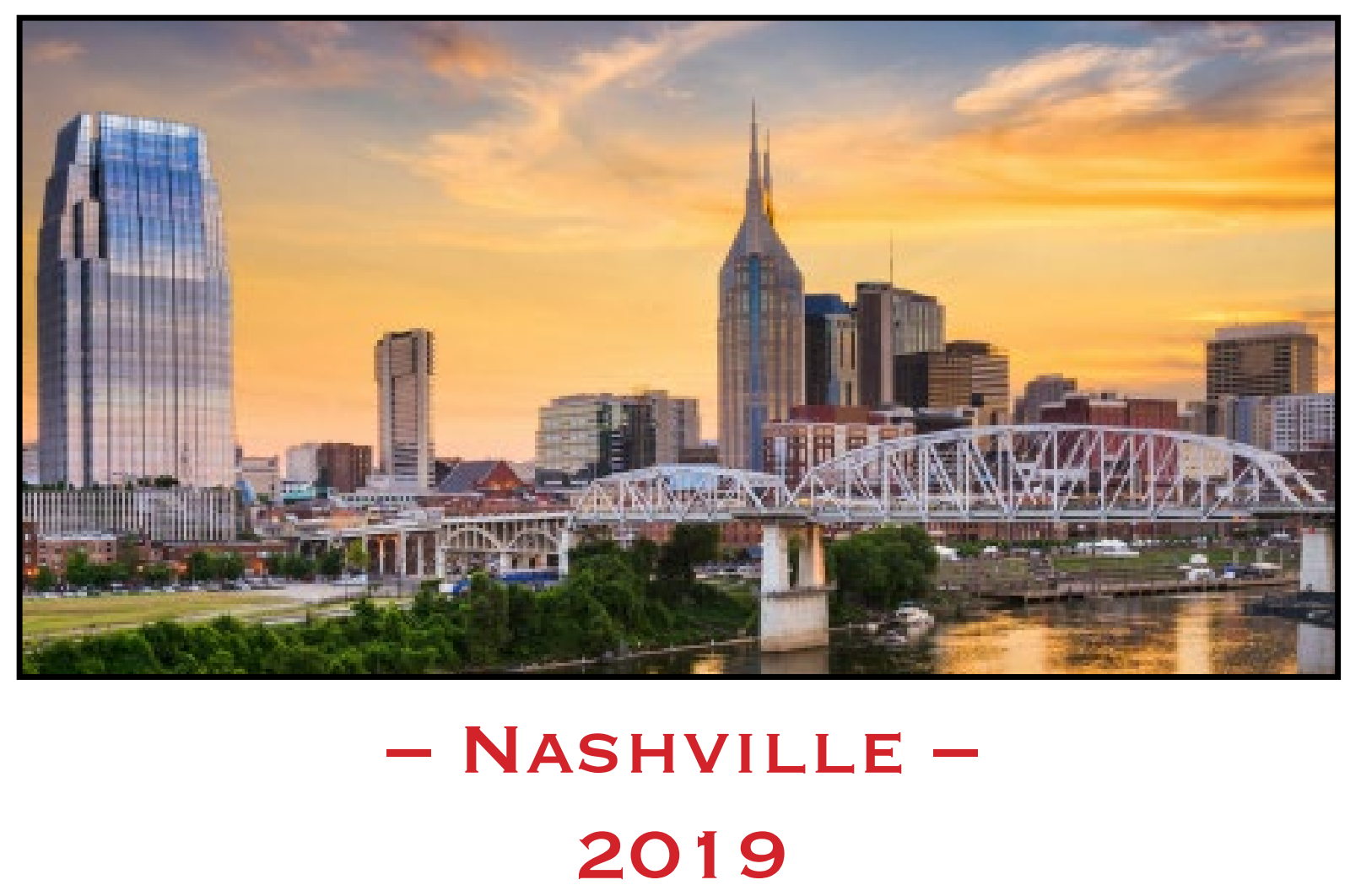

March 21 - 23, $2019 \cdot$ Belmont University - Nashville 